\title{
慢性血液透析患者にみられる高ホモシステイン 血症の治療法の検討
}

\author{
坂田 洋一目黒 輝 雄*1 \\ 自治医科大学分子病態研究部 慶生会目黒医院*1
}

key words : 慢性血液透析, 高ホモシステイン血症, 葉酸, ビタミン B12

〈要旨〉

血中ホモシステイン $(\mathrm{Hcy})$ レベル高値は, 血栓症や動脈硬化の危険因子の一つであることが最近明らかにされた. 腎不全患者にみられる高 Hcy 血症の原因は, 腎不全による排泄障害と代謝障害が产の原因として考えられている. 慢性血液透析 (HD) 患者の Hcy レベルを低下させるには，ビタミン B6，ビタミン B12 および葉酸の高用量，長期 間投与が必要であるといわれている。本研究では，そのうち最も効果の著明な葉酸について，投与方法と，至適量 の検討を行った．対象はHD 患者 180 名で，兴のうち血中 Hcy レベルが $35 \mathrm{nmol} / \mathrm{m} l$ 以上の患者を，薬剤，投与方 法の違いにより, 無作為にいくつかの群に分けて検討した. 葉酸 $5 \mathrm{mg}$ を連日投与 4 週間, 透析日のみに投与 4 週間, および，透析日のみに 4 週間投与した後，週の最終透析日の後にのみ，さらに 24 週間投与した群に分けた。結果， 連日投与群，および，各透析日後にのみ投与した群では，血中葉酸レベルは，乥れ光れ正常值上限の 60 倍および， 7 倍に上昇したが，Hcy レベルの低下はいずれもほぼ等しく，約 $57 \%$ であった，予め，透析日のみに投与し，兴の 後，24 週間，週に 1 回のみ投与し，中止後，さらに 16 週間経過を観察した群の解析からは，血中葉酸レべルを正常 值上限の 2 倍から 4 倍くらいに維持すれば，総 Hcy レベルを低值に維持することが可能であるが， 2 倍以下になる と再上昇することが示された。透析により Hcy の約 $40 \%$ が除去されることを考慮すると, $60 \mathrm{nmol} / \mathrm{m} l$ 以下の高 Hcy 血症の患者では，上記のような最小量の葉酸投与で，葉酸レベルを正常の 2 倍から 4 倍に維持すれば，総 Hcy レベルを正常值以内に保つことが可能であることが示唆された。

\section{Treatment of hyperhomocysteinemia in hemodialysis patients}

Yoichi Sakata, Teruo Meguro*1

Division of Cell and Molecular Medicine, Jichi Medical School ; Keiseikai Meguro Hospital*1

Experimental and epidemiological studies have shown that hyperhomocysteinemia is a risk factor in thrombosis and arteriosclerosis. Although the exact mechanism for an increase in plasma homocysteine (Hcy) in patients with renal failure is unknown, supplementation with higher doses of folic acid (folate), vitamin B6 (VB6) and vitamin B12 (VB12) induces a significant reduction in Hcy levels. In this study, we have tried to assess the optimal giving way and dosage of folate in hemodialysis (HD) patients.

The subjects consisted of $180 \mathrm{HD}$ patients (mean age : $57.2 \pm 11.8$ years and HD history : $9.4 \pm 6.7$ years). There was no significant correlation between Hcy level and HD history. In addition, the efficiency of HD for Hcy removal (about $40 \%$ reduction) did not depend on the kind of dialysis membrane or whether the patients had diabetes mellitus. The patients were, divided by Hcy level $>35 \mathrm{nmol} / \mathrm{m} l$ ) at random into several study groups as follows : 1 . peroral administration of coenzyme-form VB6 (30 mg/day), coenzyme-form VB12 (0.5 mg/ day), or folate ( $5 \mathrm{mg} /$ day), (each group, $n=9$ ) every day for 4 weeks ; 2. peroral administration of either folate ( $5 \mathrm{mg} /$ once) or folate with VB12 $(0.5 \mathrm{mg} /$ once), (each group, $\mathrm{n}=9)$ on HD days ("Pulse Administration") for 4 weeks. 3. Pulse Administration after 4 weeks, peroral administration of folate ( $5 \mathrm{mg} /$ once) once a week on the final HD day for 24 weeks (each $n=15$ ). The study was done stepwise from 1 to 3 . We measured the level

坂田 洋一 自治医科大学分子病態研究部 $\quad$ T 329-0498 栃木県河内郡南河内町薬師寺 3311-1 (0285-58-7397)

Yoichi Sakata Fax 0285-44-7817

〔受付：平成 12 年 9 月 6 日, 受理 : 平成 12 年 11 月 7 日〕 
of plasma folate, VB6, VB12, and total Hcy during and after administration. Our results suggest that in peroral administration, folate was most effective to reduce the total Hcy level (approx. 57\% reduction). Furthermore, for hyperhomocysteinemic patients whose levels were below $60 \mathrm{nmol} / \mathrm{m} l$, the maintenance of plasma folate level, from 2 to 4 times higher than normal was necessary to maintain plasma Hcy at a normal level.

\section{緒 言}

慢性透析患者は血管障害を高頻度に合併する。心血 管障害や脳血管障害の発症は生命予後を大きく左右す る. 血液透析 (HD) 患者にみられる動脈硬化や血栓症 の原因の詳細は不明であるが，最近，ホモシステイン が独立した危険因子であることが明らかにされた ${ }^{1)}$. 腎不全患者にみられる高ホモシステイン血症は, 腎不 全による排泄障害と代謝障害がその原因として考兄ら れている．ホモシステインの体内代謝に関与するビ夕 ミン B6（VB6），ビタミン B12（VB12）および葉酸の 投与が HD 患者の血中ホモシステインレベルの低下 に有効であり, なかでも葉酸の投与が最も効果的で, 例えば $10 \mathrm{mg}$ /日以上の高用量の投与が必要であると 報告されている ${ }^{2}$. しかし, 葉酸の高用量, 長期投与は, 胃腸障害を起こしたり，VB12 の低下を招き，末梢神経 障害を惹起する可能性がある，現在までに，果たして どのレベルの葉酸投与が高ホモシステイン血症の治療 に必要十分であるかの検討や，投与法の詳細な解析は ない. 本研究では, 慢性 HD 患者を対象に, この点に 焦点を絞り検討した。

\section{I．対象および方法}

\section{1. 対象患者}

外来管理中の HD 患者 180 名を対象にした。男性 114 例，女性 66 例，平均年齢は $57.2 \pm 11.8$ 歳，平均 $\mathrm{HD}$ 歴は 9.4 6 6.7 年であった。薬凧の服用方法毎に連 日投与群 $($ 各 $\mathrm{n}=9$ ), 毎回透析日投与 (パルス投与) 群 (各 $\mathrm{n}=9$ )に分け, さらに, パルス投与後, 引き続き週 1 回 $\mathrm{HD}$ 日投与群を, 週 3 回 $\mathrm{HD}(\mathrm{n}=15$, 男性 11 例, 女性 4 例， $51.6 \pm 12.0$ 歳，9.5 55.7 年）群，および， 週 2 回 $\mathrm{HD}$ 患者 $(\mathrm{n}=15$, 男性 12 例, 女性 3 例, $58.9 \pm$ 11.3 歳, $3.6 \pm 2.9$ 年)群に分けた。各群の患者は, 投 与前レベルが $35 \mathrm{nmol} / \mathrm{m} l$ 以上の症例を無作為に抽出 した，薬剤の投与と検査に関しては，主旨を説明し， 患者の同意を得た上で，施行した。

\section{2. 投与方法}

補酵素型 VB6(ピリドキサール； $30 \mathrm{mg} / 1$ 回), 補酵 素型 VB12（メチコバラミン; $0.5 \mathrm{mg} / 1$ 回), 葉酸
(フォリアミン； $5 \mathrm{mg} .1$ 回）をそれぞれ単独，あるい はVB12 と葉酸の併用で経口投与した。薬剂の服用方 法は, 連日投与群は夕食後, パルス投与群は毎回の HD 後,パルス投与後,引き続き週 1 回投与した群は週 3 回 $\mathrm{HD}$ ，抢よび, 週 2 回 HD 患者とも, 週の最終 HD 後と した。連日投与，およびパルス投与群は 4 週間投与と した。 パルス投与後, 週 1 回投与群は, その後, 24 週 間継続投与した。

\section{3. 採血と測定}

測定のための検体は, $\mathrm{HD}$ 前採血は, 薬剤投与後の次 の $\mathrm{HD}$ 前に, $\mathrm{HD}$ 後採血は, $\mathrm{HD}$ 終了後, 薬剤投与前に 採取した。血中葉酸値（正常值： $2.4 \sim 9.8 \mathrm{ng} / \mathrm{m} l$ ), VB6 值 (正常值：3.6 $18.0 \mathrm{ng} / \mathrm{m} l$ ), VB12 值 (正常 值: 233 914 pg/ml), およびホモシステインレベル （基準範囲：3.0 $14 \mathrm{nmol} / \mathrm{m} l$ ) 測定検体は，それぞれ の測定の採血注意事項に従い採取し, 速やかに血漿分 離後, 冷凍保存した。 ホモシステインは, 7-Fluoro-4sulfamoyl-2，1，3-benzoxadiazole (ABD-F)（同仁 化学)を用いた HPLCでtHcy 測定を行った。測定は テイジン・エスアールエルラボに依頼して施行した。

\section{II. 結 果}

\section{1. 透析とホモシステインレベル}

図 1 に今回対象とした全患者の tHcy 值の透析歴別 分布を示す. tHcy レベルと透析歴の長さには相関は みられなかった。また 180 例中 4 例は正常レベルで あったがいずれも肝硬変など蛋白質合成障害を有する 患者であった。 tHcy レベルが $110 \mathrm{nmol} / \mathrm{m} l$ 以上を示 す患者も 180 例中 7 例存在した。まず，透析による除 去率を，透析前後の tHcy レベルにより検討した（図 2). 約 40\%のホモシステインが透析で除去された（図 $2 \mathrm{~A})$. 透析前 $\mathrm{tHcy}$ レベルの異なる患者を選んで検討 すると，透析により除去されても，次回透析までには， ほぼ元の各患者のレベルまで tHcy レベルが上昇する ことが確認された (図 $2 \mathrm{~B}$ )。糖尿病の有無により結果 に差はみられなかった。また透析膜の違いは結果に有 意な影響を与えなかった。これらの結果を基に薬剤投 与の患者は, 透析歴, 糖尿病の有無, 透析膜の差の因 子を特に考慮せず，無作為に抽出した。 


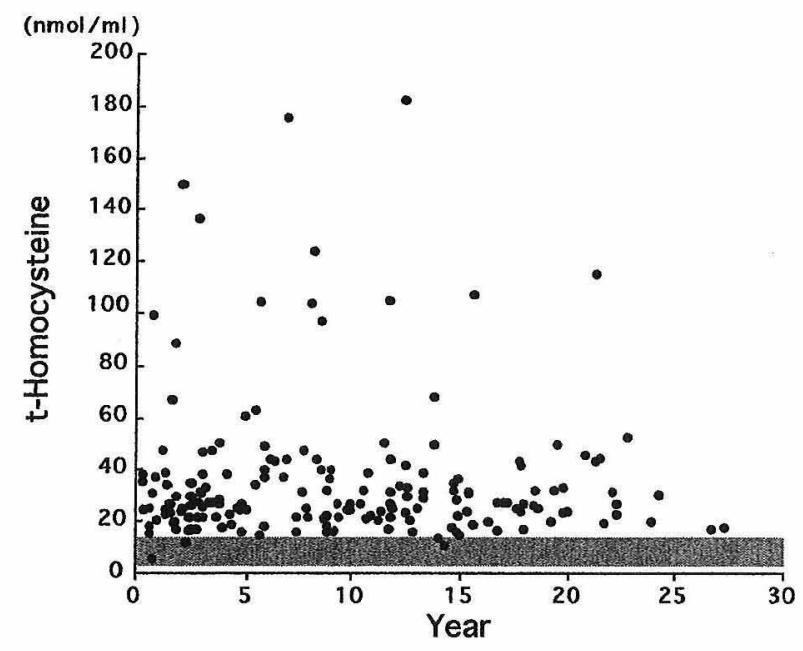

図 1 血液透析患者の透析歴と総ホモシステイン レベル $(\mathrm{n}=180)$
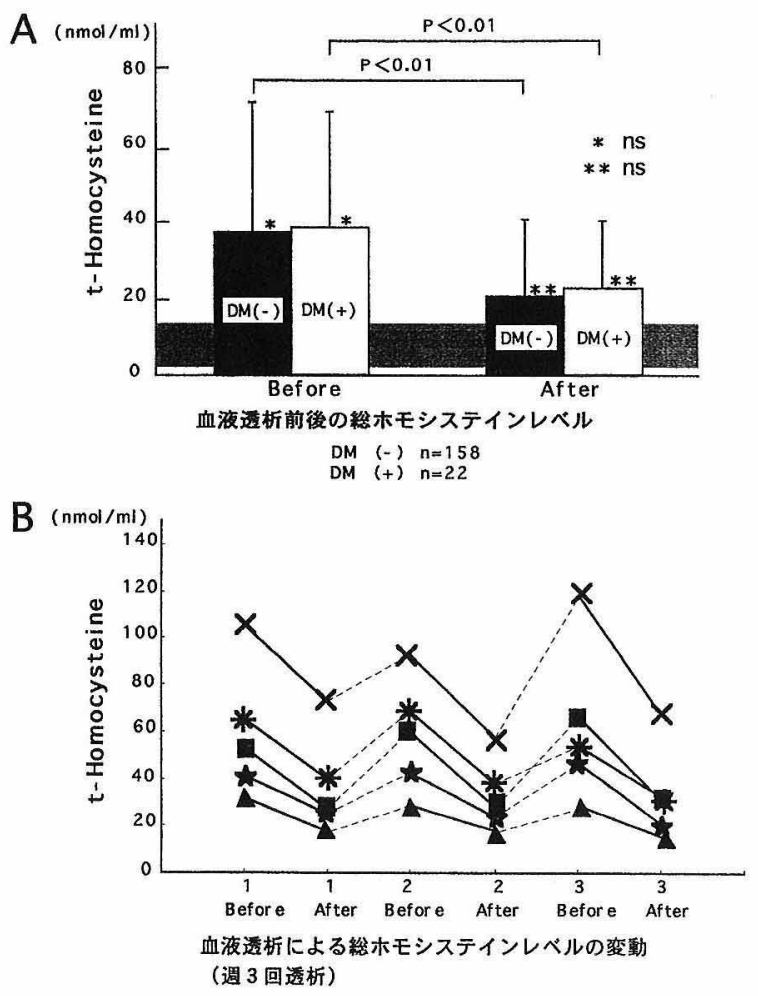

図 2

\section{2. 薬剤投与}

1) 連日投与

$40 \mathrm{nmol} / \mathrm{m} l$ 以上の異常値を示す患者を抽出し, 葉 酸 $(5 \mathrm{mg} /$ 日), VB12 (0.5 mg/日), VB6 (30 mg/日) のそれぞれを単独で，連日 4 週間投与した，投与前と， 投与終了日の次の HD 前に tHcy レベルを測定した結 果を図 3 に示す。経口薬剤（市販）の最小単位量投与 では, VB6 レベルは $26.8 \pm 16.8 \mathrm{ng} / \mathrm{m} l, V B 12$ レベル は $1079 \pm 536.3 \mathrm{pg} / \mathrm{m} l$, 葉酸は $386.7 \pm 76.4 \mathrm{ng} / \mathrm{m} l$ ま

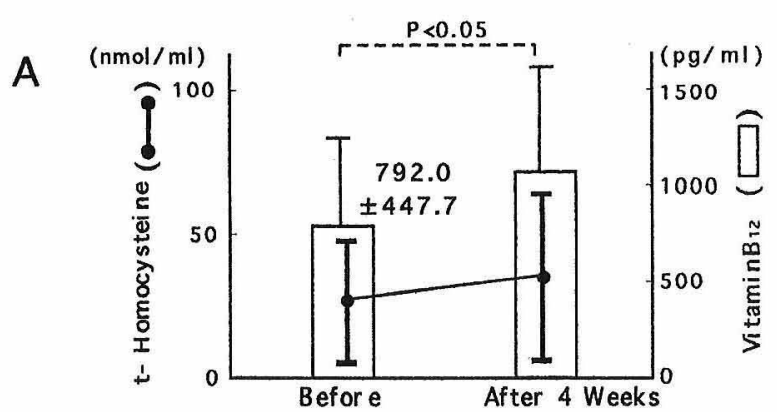

B
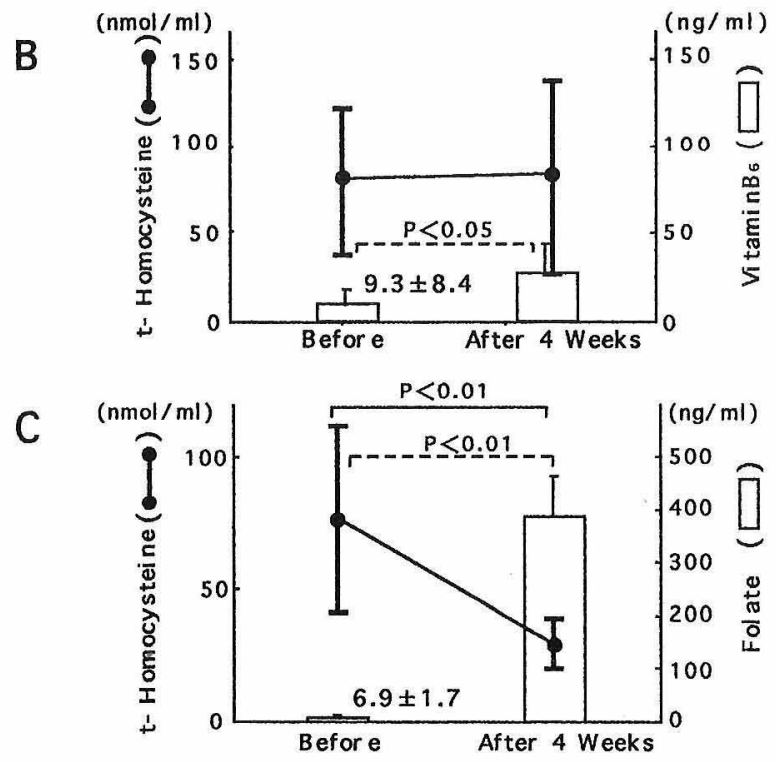
$\mathrm{A}$ ：ビタミン $\mathrm{B} 12$ 投与 $(0.5 \mathrm{mg} /$ 日)
$\mathrm{B}$ : ビタミン $\mathrm{B} 6$ 投与 $(30 \mathrm{mg} /$ 日)
$\mathrm{C}:$ 葉酸投与 $(5 \mathrm{mg} /$ 日)

図 3 連日投与による総ホモシステインレベルの 変動

で上昇した。 tHcy レベルは葉酸投与群のみ, 投与前 $76.6 \pm 35.5 \mathrm{nmol} / \mathrm{m} l$ から, 4 週間後 $29.6 \pm 9.5 \mathrm{nmol} /$ $\mathrm{m} l$ へと約 $57 \%$ 低下した。

\section{2 ) パルス投与}

$35 \mathrm{nmol} / \mathrm{m} l$ 以上の患者を抽出し, 葉酸単独, あるい は葉酸とVB12を 4 週間, 透析後のみに投与した. 1 回 投与量は連日投与群と同じ量を用いた。投与終了後, 次の $\mathrm{HD}$ 前の葉酸レベルは $53.7 \pm 16.2 \mathrm{ng} / \mathrm{m} l$ まで上 昇し, tHcy レベルは投与前 $64.0 \pm 19.8 \mathrm{nmol} / \mathrm{m} l$ が $25.7 \pm 3.5 \mathrm{nmol} / \mathrm{m} l$ まで低下した. 低下率は連日投与 群とほぼ同じで約 57\%であった (図 4 A)。VB12 (0.5 $\mathrm{mg} / 1$ 回）の併用は結果に影響を与兄なかった（図 4 B).

\section{3 ) 維持療法}

葉酸のパルス投与終了後, 約 6 週間後には再度, tHcy レベルの再上昇傾向が観察された（data not shown)，そこで，tHcy レベルを維持するための葉酸 の最小維持量の検討を行った. 4 週間パルス投与後, 引 き続き, 週の最終透析日のみに透析後, $5 \mathrm{mg} / 1$ 回の葉 
A
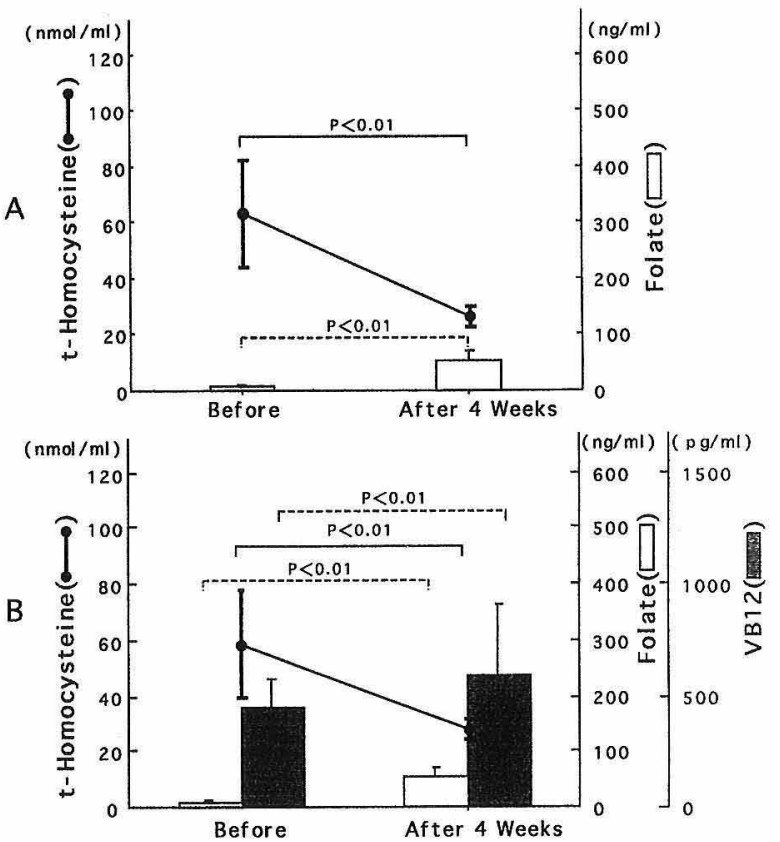

$A$ : 葉酸 $(5 \mathrm{mg} / 1$ 回) 投与

$B$ : 葉酸 $(5 \mathrm{mg} / 1$ 回 $)+V B 12(0.5 \mathrm{mg} / 1$ 回 $)$ 投与

図 4 葉酸预より゙葉酸 VB12 の血液透析日投与 による総ホモシステインレベルの変動

酸を投与し, 経過を観察した.葉酸と tHcy レベルはそ の次の透析前 (葉酸最高值), および, 最終日の透析後 (葉酸最小值)に採血し，検討した，透析効果の影響を 考慮して, 週 2 回および週 3 回透析患者を対象に選ん だ (図 $5 \mathrm{~A}, \mathrm{~B}$ )。週 2 回透析群は比較的透析歴の短い ものが多かった. 週 3 回群の, 葉酸レベルは次の透析 前で $42.5 \pm 20.2 \mathrm{ng} / \mathrm{m} l$, 最終日の透析後で $24.6 \pm$ $12.9 \mathrm{ng} / \mathrm{m} l$ を示した。 週 2 回群のレベル (data not shown）と，3回群との間に有意差は認められなかっ た. tHcy レベルにはパルス後の值から殆ど変動はみ られず, 投与前の約 $40 \%$ 前後の值に維持された. また, 葉酸投与中止後の解析からは, 葉酸レベルが $15.6 \pm$ $8.5 \mathrm{ng} / \mathrm{ml}$ 以下になると, tHcy レベルが再上昇する ことが示された。

経過を通じ，葉酸投与によると思われる胃腸障害を 訴光る患者は 1 例も認められなかった。 また 28 週間の 葉酸投与後の患者血中 VB12 レベルは $655.9 \pm 333.3$ $\mathrm{pg} / \mathrm{m} l$ で，投与前 $731.0 \pm 317.0 \mathrm{pg} / \mathrm{m} l$ に比べ殆ど低 下はみられなかった。

\section{III. 考察ならびに結論}

高ホモシステイン血症が血栓症や動脈硬化の独立し た危険因子であることはおおかたの認めるところであ る. その機序については多くの説が提唱されている. 例えば，Harlan ら ${ }^{3)}$ による活性化酸素および $\mathrm{H}_{2} \mathrm{O}_{2}$ の
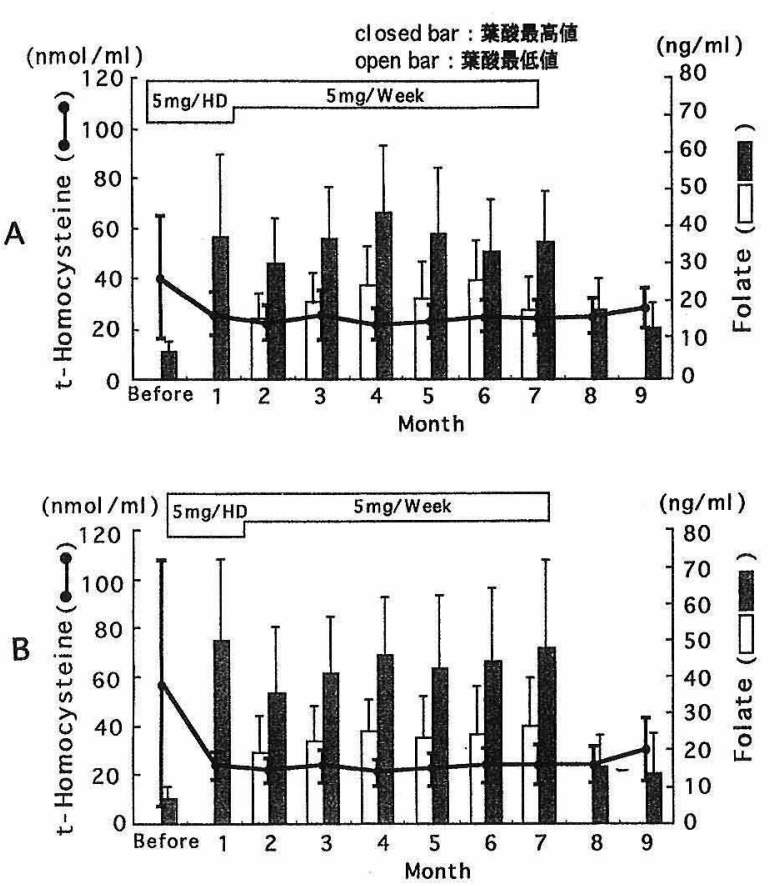

$A ：$ 週 2 回透析, B : 週 3 回透析

図 5 葉酸投与によるホモシステインレベルの変 動

産生を介する血管内皮細胞の酸化障害, トロンボモ ジュリンの発現低下による活性化プロテインC 産生 の低下 ${ }^{4)}$,さらには単球細胞上の組織因子発現の誘導 ${ }^{5)}$ など，内皮障害から血栓形成に関与する因子までへの ホモシステインの影響が検討されている，HD患者に おける高ホモシステイン血症もまた同様の血管障害の 危険因子であることが報告されている1，しかし，HD 患者に高ホモシステイン血症が高頻度にみられるメカ ニズムは必ずしも明らかではない，血漿からのクリア ランスの著しい低下がその原因であると示唆する報告 はあるが6)，ホモシステインの尿中排汹量がその産生 量の $0.1 \%$ にすぎないことから?腎不全による排泄障 害のみでは説明できない，一方，メチオニンから合成 されるホモシステインの代謝は，セリンと縮合してシ スタチオニンへと変化する経路と, 再メチル化されて メチオニンに戻る経路を持つ. HD 患者に, 再メチル化 に関与する酵素の補酵素としての VB12 や補基質と しての葉酸，さらにはシスタチオニン合成酵素の補酵 素であるVB6 などの高用量を投与すると，高ホモシ ステイン血症が改善することから，これらの経路に障 害が存在する可能性が示唆されている8). しかしなが ら, $110 \mathrm{nmol} / \mathrm{m} l$ 以上の重症高ホモシステイン血症の みられる我々の症例でも，これらのビタミンの血中レ ベルは，正常範囲内にあった (data not shown)。ま た，効果発現には高用量のビタミン投与が必要である ことが報告されている。従って，おそらくは慢性腎不 
全ではこれらの補䤃素，補基質の作用を競合阻害する 病態が生じているものと思われる。この両経路のうち 再メチル化侍与する関与素の $\mathrm{Km}$ はシスタチオニン 合成酵素の $\mathrm{Km}$ より小さい。このことは，再メチル化 反応が細胞内ホモシステイン濃度により強い影響を持 つことを示唆する。㧍そらく,VB6 投与よりVB12 や， 葉酸の投与のほうが高ホモシステイン血症の改善に有 効なのはこのことも関与していると思われる.

ところで，高ホモシステイン血症の治療を考える上 で，まずそれぞれの薬剤の特性を検討すると，いくつ かの問題点が存在する.VB12 は経口投与では, 吸収効 率が悪い，筋注では注射部位に硬結，静注では時にア ナフィラキシーショックがみられる.VB6 は大量長期 投与では未梢神経障害がみられる。葉酸は静注不可で ある。また，長期間投与でVB12 レベルが低下し，末 梢神経障害が出現することがある，そこで，患者に負 担が少なく，副作用を可能な限り抑えることを意図し て，まずそれぞれの市販薬単位の最小量の経口投与を 4 週間試みた. 結果, 葉酸投与のみに効果が確認できた ので (図 3)，葉酸投与を治療の中心とすることとし， さらに投与方法と量を検討した，量に関しては，投与 法を変えることで血中葉酸レベルを変化させ，どのレ ベルに維持することで，有効なホモシステイン低下効 果が得られるかにより検討した。葉酸 $5 \mathrm{mg}$ を毎回透 析後に服用させるパルス療法 4 週間では，葉酸レベル は正常上限の 7〜 8 倍にしか上昇しなかったが, 連日投 与とほほ同じホモシステインレベル低下効果がみられ た。ところが，葉酸投与を中止すると，4〜6週間後に は再度血中ホモシステインレベルは上昇傾向を示した (data not shown)。葉酸は新鮮な青野菜やメロン，バ ナナなどの果物に大量に含まれる。しかし，加熱によっ て破壊されるために血液透析患者が大量に経口㩒取す ることは不可能である。しかも，保存量に対して一日 の必要量が多いためにパルス療法数週間後には葉酸レ ベルが低下して，再上昇してきたものと思われる。 そ こでパルス療法後に, 葉酸 $5 \mathrm{mg}$ を週 1 回のみ, 透析後 に服用することで，ホモシステインレベルを維持でき ないかを検討した，図 5 からは，この投与により，1 週 間の間，葉酸レベルは正常上限の約 2 倍から 4 倍の中 間值で経過することが, 推測される. tHcy レベルの上 昇がみられないことから，このレベルの葉酸值の上昇 で tHcy レベルを低值に維持することが可能であると 思われる。ささらに，投与中止後の結果加らは，正常值 上限の 2 倍以下に葉酸值が低下すると，再上昇するこ とが示された，約 6 か月間の投与中，胃腸障害を訴え た患者は 1 例もなく, VB12 レベルも低下せず, 末梢神
経障害を示唆する症状を訴えた患者もいなかったこと から，この投与方法は長期間投与が可能な治療法であ ると考えられる．ホモシステインレベルが透析前の 40\%近傍に低下し，さらに透析によりその約 40\%は除 去されることから透析前に $60 \mathrm{nmol} / \mathrm{m} l$ 以上の高值を 示すような患者を除いて, 本治療法で, 長期にホモシ ステインレベルを基準值内に維持することは可能であ ると思われる。また，図 3 抢よび図 4 から葉酸の高用 量投与は不要であること，および，その効果には上限 があることが示唆された。ところで，葉酸とVB12 は 再メチル化経路に関与するが, 葉酸は補基質として, またVB12 はメチオニンシンターゼの補酵素として 作用する，従って，両者を併用すると，相加的な効果 により，さらに tHcy レベルを低下しうる可能性があ る。しかしながら，本研究の連日投与例でも明らかな ように，経口投与では，それほどVB12 の血中レベル の上昇は望めない. そこで, $100 \mathrm{nmol} / \mathrm{m} l$ 以上を示す 重症高ホモシステイン血症の患者には, 現在, VB12 の $0.5 \mathrm{mg} / 1$ 回静注投与と葉酸の併用療法を試みている。 長期投与による影響を含め, 今後, さらに本併用療法 の得失についての解析を進めていく予定である.また, ホモシステインレベルを低值に維持することにより， 果たして透析患者の血管障害の頻度が低下するかとい う問題は, 臨床的には最も重要であり, 興味深いこと でもある. 結果の解粕にはなお，今後数年にわたる長 期間の検討が必要であると思われる。

\section{文献}

1) Bachmann J, Tepel M, Radit H, Riezier R, Graefe $\mathrm{U}$, Langer $\mathrm{K}$, Zidek $\mathrm{W}$ : Hyperhomocyteinemia and the risk for vascular disease in hemodialys patients. J Am Soc Nephrol $6: 121-125,1995$

2) Chaauveau P, Caadefaux B, Coude M, Aupetit J, Kamoun $\mathrm{P}$, Jungers $\mathrm{P}$ : Long term folic acid supplementation lowers elevated plasma homocysteine level in chronic renal failure. Miner Electrolyate Metab 22:106-109, 1996

3) Starkebaum G, Harlan JM : Endothelial injury due to copper-catalyzed hydorogen peroxide generation from homocysteine. J Clin Invest $77: 1370-1376$, 1986

4) Hayashi T, Honda G, Suzuki K : An atherogenic stimulus homocysteine inhibits cofactor activity of thrombomodulin expression in human umbilical vein cells. Blood 79 : 2930-2936, 1992

5) Khajuria A, Houston DS : Induction of monocyte tissue factor expression by homocysteine: a possible mechanism for thrombosis. Blood $96: 966-972$, 
2000

6) Guttormsen AB, Ureland PM, Svarstad E, Refsum $\mathrm{H}$ : Kinetic basis of hyperhomocysteinemia in patients with chronic renal failure. Kidney Int 52 : 495-502, 1997

7) Ureland PM, Refsum H : Plasma homocysteine, a risk factor for vascular disease: Plasma levels in health, disease and drug therapy. J Lab Clin Med
$114: 473-450,1989$

8) Robinson K, Gupta A, Dennis V, Arheart K, Caaudhary D, Green R, Vigo P, Mayer EL, Selhub J, Kutner M, Jacobsen DW: Hyperhomocysteinemia confers an independent increased risk of atherosclerosis in end-stage renal disease and is closely linked to plasma folate an pyridoxine concentrations. Circulation $74: 2743-2748,1996$ 